2013

\title{
Sustainable Agro-Food Industrial Wastewater Treatment Using High Rate Anaerobic Process
}

\author{
Rajinikanth Rajagopal \\ Agriculture and Agri-Food Canada \\ Noori M. Cata Saady \\ Agriculture and Agri-Food Canada \\ Michel Torrijos \\ Laboratory of Environmental Biotechnology \\ Joseph V. Thanikal \\ Caledonian Centre for Scientific Research \\ Yung Tse Hung \\ Cleveland State University, y.hung@csuohio.edu
}

Follow this and additional works at: https://engagedscholarship.csuohio.edu/encee_facpub

How does access to this work benefit you? Let us know!

\section{Recommended Citation}

Rajagopal, Rajinikanth; Cata Saady, Noori M.; Torrijos, Michel; Thanikal, Joseph V.; and Hung, Yung Tse, "Sustainable Agro-Food Industrial Wastewater Treatment Using High Rate Anaerobic Process" (2013). Civil and Environmental Engineering Faculty Publications. 108.

https://engagedscholarship.csuohio.edu/encee_facpub/108

This Article is brought to you for free and open access by the Civil and Environmental Engineering at EngagedScholarship@CSU. It has been accepted for inclusion in Civil and Environmental Engineering Faculty Publications by an authorized administrator of EngagedScholarship@CSU. For more information, please contact library.es@csuohio.edu. 
Review

\title{
Sustainable Agro-Food Industrial Wastewater Treatment Using High Rate Anaerobic Process
}

\author{
Rajinikanth Rajagopal $^{1, *}$, Noori M. Cata Saady ${ }^{1}$, Michel Torrijos ${ }^{2}$, Joseph V. Thanikal ${ }^{3}$ \\ and Yung-Tse Hung ${ }^{4}$
}

1 Dairy and Swine Research and Development Centre, Agriculture and Agri-Food Canada, Sherbrooke, Quebec J1M0C8, Canada; E-Mail: noori.saady@agr.gc.ca

2 INRA, UR50, Laboratory of Environmental Biotechnology, Avenue des Etangs, Narbonne, F-11100, France; E-Mail: michel.torrijos@supagro.inra.fr

3 Caledonian Centre for Scientific Research, Department of Built and Natural Environment, Caledonian College of Engineering, P.O. Box 2322, CPO Seeb 111, Muscat, Sultanate of Oman; E-Mail: joseph@caledonian.edu.om

4 Department of Civil and Environmental Engineering, Cleveland State University, Cleveland, OH 44115, USA; E-Mail: yungtsehung@yahoo.com

* Author to whom correspondence should be addressed; E-Mail: rajinikanth.rajagopal@agr.gc.ca and rrajinime@yahoo.co.in; Tel.: +1-819-780-7303; Fax: +1-819-564-5507.

Received: 5 January 2013; in revised form: 15 February 2013 / Accepted: 5 March 2013 /

Published: 15 March 2013

\begin{abstract}
This review article compiles the various advances made since 2008 in sustainable high-rate anaerobic technologies with emphasis on their performance enhancement when treating agro-food industrial wastewater. The review explores the generation and characteristics of different agro-food industrial wastewaters; the need for and the performance of high rate anaerobic reactors, such as an upflow anaerobic fixed bed reactor, an upflow anaerobic sludge blanket (UASB) reactor, hybrid systems etc.; operational challenges, mass transfer considerations, energy production estimation, toxicity, modeling, technology assessment and recommendations for successful operation.
\end{abstract}

Keywords: anaerobic digestion; agro-food wastewater; biogas; high-rate systems; sustainable wastewater treatment 


\section{Introduction}

Agro-industries are major contributors to worldwide industrial pollution. Effluents from many agro-food industries are a hazard to the environment and require appropriate and a comprehensive management approach. Worldwide, environmental regulatory authorities are setting strict criteria for discharge of wastewaters from industries. As regulations become stricter, there is now a need to treat and utilize these wastes quickly and efficiently. With the tremendous pace of development of sustainable biotechnology, substantial research has been devoted recently to cope with wastes of ever increasing complexity generated by agro-industries. Anaerobic digestion is an environmentally friendly green biotechnology to treat agro-food industrial effluents. In addition, the carbon emission and, therefore, the carbon footprint of water utilities is an important issue nowadays. In this perspective, it is essential to consider the prospects for the reduction of the carbon footprint from small and large wastewater treatment plants. The use of anaerobic treatment processes rather than aerobic would accomplish this purpose, because no aeration is required and the biogas generated can be used within the plant. Anaerobic digestion is unique, as it reduces waste and produces energy in the form of methane. Not only does this technology have a positive net energy production, but the biogas produced can also replace fossil fuel; therefore, it has a direct positive effect on greenhouse gas reduction. Thus, the carbon-negative anaerobic digestion process is considered as a sustainable wastewater treatment technology, which also provides the best affordable (low-cost) process for public health and environmental protection, as well as resource recovery. The attractiveness of biogas technology for large scale applications has been limited, essentially, because of the slow rate and process instability of anaerobic digestion. The slow rate means large digester volumes (and consequently, greater costs and space requirements) and process instability means the lack of assurance for a steady energy supply. These two major disadvantages of conventional anaerobic processes have been overcome by high rate anaerobic reactors, which employ cell immobilization techniques, such as granules and biofilms. Thus, various reactor designs that employ various ways of retaining biomass within the reactor have been developed over the past two decades. The purpose of this article is to summarize the current status of the research on high rate anaerobic treatment of agro-food industrial wastewater and to provide strategies to overcome some of the operational problems.

\section{Agro-Food Industrial Wastewaters}

About $65 \%-70 \%$ of the organic pollutants released in the water bodies in India are from food and agro-product industries, such as distilleries, sugar factories, dairies, fruit canning, meat processing and pulp and paper mills [1]. Similarly, the pulp and paper industry is one of the most significant industries in Sweden, as well as many other countries around the world, and the products constitute important industrial trade in terms of value of production [2]. Wine production is one of the leading agro-food industries in Mediterranean countries, and it has also attained importance in other parts of the world, such as Australia, Chile, the United States, South Africa and China, with increasing influence on the economy of these countries [3]. The wine industry generates huge volumes of wastewater that are mainly originated from several washing operations, e.g., during crushing and pressing of the grapes, cleaning the fermentation tanks, containers, other equipment and surfaces. In addition to this, olive oil 
industries have gained fundamental economic importance for many Mediterranean countries [4]. Malaysia presently accounts for $39 \%$ of world palm oil production and $44 \%$ of world exports [5]. Due to its surplus production, a huge amount of polluted wastewater, commonly referred to as palm oil mill effluent (POME) is generated. Fia et al. [6] reported that in coffee producing regions, such as Brazil, Vietnam and Colombia, the final effluent produced from this process has become a large environmental problem, creating the need for low cost technologies for the treatment of wastewater. Nieto et al. [7] determined the potential for methane production from six agro-food wastes (beverage waste, milled apple waste, milk waste, yogurt waste, fats and oils from dairy wastewater treatment and cattle manure). The wastewater generation varies from country to country. For instance, world wine production in 2011 was estimated to be about 270 million hectoliters, with the European Union producing 152 million hL (France with 50.2 million hL; Italy, with 40.3 million hL; Spain, with 35.4 million $\mathrm{hL}$ ), whereas it was estimated to be 18.7, 15.5, 11.9, 10.6, 9.3 and 2.3 million hL for countries, such as the USA, Argentina, Australia, Chile, South Africa and New Zealand, respectively [8]. The annual worldwide production of olive oil is estimated to be about 1750 million metric tons, with Spain, Italy, Greece, Tunisia and Portugal being the major producers, and about 30 million cubic meters of oil mill wastes (OMW) are generated annually in the Mediterranean area during the seasonal extraction of olive oil $[4,9]$.

The composition and concentration of different agro-food wastewaters vary from low (wash water from sugar mill or dairy effluents) to high strength substrates (cheese, winery and olive mill wastewaters), particularly in terms of organic matter, acids, proteins, aromatic compounds, available nutrients, etc. $[1,3,10]$. The main parameters of the agro-food industrial wastewater, such as total solids (TS), total nitrogen (TN), total phosphorus (TP) and biochemical and chemical oxygen demand (BOD and COD), respectively are given in Table 1.

Table 1. Characteristics of typical agro-food industrial wastewater.

\begin{tabular}{lcccccc}
\hline Industry & $\begin{array}{c}\mathbf{T S} \\
\left(\mathbf{m g ~ L}^{-\mathbf{1}}\right)\end{array}$ & $\begin{array}{c}\mathbf{T P} \\
\left(\mathbf{m g ~ L}^{-\mathbf{1}}\right)\end{array}$ & $\begin{array}{c}\mathbf{T N} \\
\left(\mathbf{m g ~ L}^{-\mathbf{1}}\right)\end{array}$ & $\begin{array}{c}\mathbf{B O D} \\
\left(\mathbf{m g ~ L}^{-\mathbf{1}}\right)\end{array}$ & $\begin{array}{c}\mathbf{C O D} \\
\left(\mathbf{m g ~ L}^{-\mathbf{1}}\right)\end{array}$ & Reference \\
\hline Food processing & - & 3 & 50 & $600-4,000$ & $1,000-8,000$ & {$[11]$} \\
Palm oil mill & 40 & - & 750 & 25 & 50 & {$[12]$} \\
Sugar-beet processing & 6100 & 2.7 & 10 & - & 6,600 & {$[13]$} \\
Dairy & $1,100-1,600$ & - & - & $800-1,000$ & $1,400-2,500$ & {$[14]$} \\
Corn milling & 650 & 125 & 174 & 3,000 & 4,850 & {$[15]$} \\
Potato chips & 5,000 & 100 & 250 & 5,000 & 6,000 & {$[16]$} \\
Baker's yeast & 600 & 3 & 275 & - & 6,100 & {$[17]$} \\
Winery & $150-200$ & $40-60$ & $310-410$ & - & $18,000-21,000$ & {$[1,3]$} \\
Dairy & $250-2,750$ & - & $10-90$ & $650-6,250$ & $400-15,200$ & {$[18]$} \\
Cheese dairy & $1,600-3,900$ & $60-100$ & $400-700$ & - & $23,000-4,0000$ & {$[1]$} \\
Olive mill & 75,500 & - & 460 & - & 130,100 & {$[19]$} \\
Cassava starch & 830 & 90 & 525 & 6,300 & 10,500 & {$[20]$} \\
\hline
\end{tabular}

Notes: ${ }^{a}$ contains flour, soybean, tomato, pepper and salt. TS: total solids; TN: total nitrogen; TP: total phosphorus; BOD: biochemical oxygen demand; COD: chemical oxygen demand. 


\section{High Rate Anaerobic Reactors}

High-rate anaerobic digesters receive increasing interest, due to their high loading capacity and low sludge production [21]. The commonly used high-rate anaerobic digesters include: anaerobic filters, upflow anaerobic sludge blanket (UASB) reactors, anaerobic baffled, fluidized beds, expanded granular sludge beds (EGSB), sequencing batch reactors and anaerobic hybrid/hybrid upflow anaerobic sludge blanket reactors [1,21].

Rajagopal et al. [22] developed high-rate upflow anaerobic filters (UAFs) packed with low-density polyethylene media for the treatment of wastewater discharged from various agro-food industries with different composition and COD concentrations viz. synthetically prepared low strength $\left(\sim 1.9 \mathrm{~g} \mathrm{COD} \mathrm{L}^{-1}\right)$, fruit canning $\left(\sim 10 \mathrm{~g} \mathrm{COD} \mathrm{L}^{-1}\right)$, winery $\left(\sim 20 \mathrm{~g} \mathrm{COD} \mathrm{L}^{-1}\right)$ and cheese-dairy $\left(\sim 30 \mathrm{~g} \mathrm{COD} \mathrm{L}^{-1}\right)$ wastewaters. High organic loading rates (OLRs) (12-27 g COD L $\mathrm{g}^{-1} \mathrm{~d}^{-1}$ ) were reported in this study. Low-density polyethylene support (29 mm high; 30-35mm diameter; density: $0.93 \mathrm{~kg} \mathrm{~m}^{-3}$; specific area: $320 \mathrm{~m}^{2} \mathrm{~m}^{-3}$ ) was able to retain between 0.7 and $1.6 \mathrm{~g}$ dried solids per support. This study concluded that the low-density polyethylene support is a good colonization matrix to increase the quantity of biomass in the reactor compared to conventional treatment systems.

In a similar study, Ganesh et al. [3] investigated the performance of upflow anaerobic fixed-bed reactors filled with low density supports of varying size and specific surface area for the treatment of winery wastewater. They found that efficiency of reactors increased with decrease in size and increase in specific surface area of the supports. A maximum OLR of $42 \mathrm{~g} \mathrm{~L}^{-1} \mathrm{~d}^{-1}$ with $80 \%$ COD removal efficiency was attained, when supports with the highest specific surface area were used. However, for long-term operation, clogging might occur in the reactors packed with small size supports.

Esparza et al. [23] reported that a pilot-scale upflow anaerobic sludge blanket (UASB) reactor treating cereal-processing wastewater at $17{ }^{\circ} \mathrm{C}$ with OLR 4-8 $\mathrm{kg} \mathrm{COD} \mathrm{m}{ }^{-3} \mathrm{~d}^{-1}$ and a hydraulic retention time (HRT) of $5.2 \mathrm{~h}$ removed $82 \%-92 \%$ of the COD. Shastry et al. [24] investigated the feasibility of a UASB reactor system as a pretreatment for hydrogenated vegetable oil wastewater. COD removal efficiency of $99 \%-80 \%$ at OLR varying in the range $1.3-10 \mathrm{~g} \mathrm{COD} \mathrm{L}^{-1} \mathrm{~d}^{-1}$ was obtained with a specific methane yield of $0.30-0.35 \mathrm{~m}^{3} \mathrm{CH}_{4} \mathrm{~kg}^{-1} \mathrm{COD}$.

Won and Lau [25] operated an anaerobic sequencing batch reactor (ASBR) to investigate the effect of $\mathrm{pH}$, HRT and OLR on biohydrogen production at $28^{\circ} \mathrm{C}$. For a carbon-rich substrate, a maximum hydrogen production rate and yield of $3 \mathrm{~L} \mathrm{H}_{2} \mathrm{~L}^{-1}$ reactor $\mathrm{d}^{-1}$ and $2.2 \mathrm{~mol} \mathrm{H}_{2} \mathrm{~mol}^{-1}$ hexose, respectively, were achieved at $\mathrm{pH} 4.5$, HRT $30 \mathrm{~h}$ and OLR $11.0 \mathrm{~g} \mathrm{~L}^{-1} \mathrm{~d}^{-1}$. A mesophilic anaerobic sequencing batch biofilm reactor (ASBBR) treating lipid-rich wastewater with OLR as much as $12.1 \mathrm{~g} \mathrm{COD} \mathrm{L}^{-1} \mathrm{~d}^{-1}$ was achieved with 90\% COD removal efficiency [26].

Shanmugam and Akunna [27] investigated the performance of a granular bed baffled reactor (GRABBR) for the treatment of low-strength wastewaters at increasing OLRs (up to $60 \mathrm{~g} \mathrm{COD} \mathrm{L}^{-1} \mathrm{~d}^{-1}$ ). They showed experimentally that GRABBR encouraged different stages of anaerobic digestion in separate vessels longitudinally across the reactor, and it had greater process stability at relatively short HRTs (1 h) with $86 \%$ methane in biogas. Bialek et al. [28] assessed the performance of two kinds of reactors (inverted fluidized bed (IFB) and expanded granular sludge bed (EGSB) reactors) treating simulated dairy wastewater. At $37{ }^{\circ} \mathrm{C}$, they obtained more than $80 \%$ of COD and protein removals with an OLR of $167 \mathrm{mg} \mathrm{COD} \mathrm{L}^{-1} \mathrm{~h}^{-1}$ and a HRT of $24 \mathrm{~h}$. 
Rajagopal et al. [29] proposed a modified UAF reactor design, called "hybrid upflow anaerobic sludge-filter bed (UASFB) reactor", to overcome problems faced by fixed bed reactors, such as clogging, short circuiting and biomass washout. This configuration contains a sludge bed in the lower part of the reactor and a filter bed in the upper part. For the treatment of wine distillery vinasse (21.7 $\left.\mathrm{g} \mathrm{COD} \mathrm{L}^{-1}\right)$ they achieved a high OLR (18 $\left.\mathrm{g} \mathrm{COD} \mathrm{L}^{-1} \mathrm{~d}^{-1}\right)$ at a short HRT $(26 \mathrm{~h})$, while maintaining high COD removal efficiencies of about $85 \%$. However, an aerobic post-treatment is required to make the effluent fit for final disposal, especially in terms of nitrogen [3,14,22]. Table 2 summarizes the performance of anaerobic digesters for the treatment of various agro-food wastewaters in terms of design and applied operational conditions, process efficiency and energy characteristics.

\section{Other Treatment Strategies to Enhance the Reactor Performance}

Biogas production can be augmented by using ample lignocellulose materials viz. agricultural and forest residues [30,31]. However, the complex lignocellulose structure limits the accessibility of sugars in cellulose and hemicellulose. Consequently, a pretreatment is essential and several potential pretreatment techniques have been developed for lignocellulose material [32].

Nkemka and Murto [31] evaluated the biogas production in batch and UASB reactors from pilot-scale acid catalyzed steam-pretreated and enzymatic-hydrolysed wheat straw. They showed that the pre-treatment increased the methane yield [0.28 $\mathrm{m}^{3} \mathrm{~kg}^{-1}$ volatile solids (VS) fed] by $57 \%$ compared to untreated straw. The treatment of straw hydrolysate with nutrient supplementation in a UASB reactor resulted in a high methane production rate $\left(2.70 \mathrm{~m}^{3} \mathrm{~m}^{-3} \mathrm{~d}^{-1}\right)$ at an OLR of $10.4 \mathrm{~g} \mathrm{COD} \mathrm{L}^{-1} \mathrm{~d}^{-1}$ and with 94\% COD reduction.

Badshah et al. [2] proved that the methanol condensate can be efficiently converted into biogas in a UASB reactor instead of methanol, with much of the smell of the feed eliminated. Bosco and Chiampo [33] reported polyhydroxyalkanoates (PHAs) (biodegradable plastic) production from milk whey and dairy wastewater activated sludge. They defined the suitable $\mathrm{C} / \mathrm{N}$ ratio, the pre-treatments required to lower the protein content and the effect of $\mathrm{pH}$ correction.

Garcia et al. [34] investigated the effect of polyacrylamide (PAM) for the biomass retention in an UASB reactor treating liquid fraction of dairy manure at several organic loading rates. They have concluded that PAM addition enhanced sludge retention and reactor performance (with a total COD removal of $83 \%$ compared to $77 \%$ removal efficiencies for UASB without polymer addition).

In order to remove ammonia nitrogen, $\mathrm{Yu}$ et al. [35] attempted to enrich anammox bacteria in sequencing batch biofilm reactors (SBBRs) with different inoculations. The maximum total nitrogen loading rate of SBBR gradually reached $1.62 \mathrm{~kg} \mathrm{~N} \mathrm{~m}^{-3} \mathrm{~d}^{-1}$, with a removal efficiency higher than $88 \%$. Few researchers [36,37] reported that anammox bacteria have slow growth rate kinetics, and hence, they are vulnerable to external conditions, such as low temperature, high dissolved oxygen and some inhibitors. Although this technique faces some complications in full-scale applications, such as long start-up and instability, anammox is still an innovative technological development in reducing ammonia from wastewater $[35,38]$. 
Table 2. Performance of anaerobic digesters for the treatment of various agro-food wastewaters.

\begin{tabular}{|c|c|c|c|c|c|c|c|c|c|c|}
\hline Substrate & $\begin{array}{c}\text { Reactor } \\
\text { type }^{\mathrm{a}}\end{array}$ & $\begin{array}{l}\text { TCOD } \\
\left(g^{-1}\right)\end{array}$ & pH & HRT (h) & $\begin{array}{c}\text { OLR } \\
\left(\mathrm{g} \mathrm{COD} \mathrm{L}^{-1} \mathrm{~d}^{-1}\right)\end{array}$ & $\begin{array}{c}\text { TCOD } \\
\text { removal } \\
(\%)\end{array}$ & $\begin{array}{l}\text { SCOD } \\
\text { removal } \\
(\%)\end{array}$ & $\begin{array}{c}\text { VFA/ } \\
\text { alkalinity }\end{array}$ & Comments & Reference \\
\hline Fruit canning & UAF & $9-11.6$ & $6-6.5$ & 12 & 19 & 68 & 81 & 0.35 & $\begin{array}{l}\text { Specific sludge loading rate (SSLR): } \\
0.56 \mathrm{~g} \mathrm{COD} \mathrm{g}^{-1} \mathrm{VSS} \mathrm{d}^{-1}\end{array}$ & \multirow[t]{2}{*}[1]{} \\
\hline Cheese dairy & UAF & $23-40$ & $6-6.5$ & 40 & 17 & 71 & 82 & 0.6 & SSLR: $0.63 \mathrm{~g} \mathrm{COD} \mathrm{g}^{-1} \mathrm{VSS} \mathrm{d}^{-1}$ & \\
\hline $\begin{array}{c}\text { Winery } \\
\text { wastewater }\end{array}$ & FBR & $18-21$ & $8-11$ & $15-23$ & $22-42$ & $65-70$ & 80 & 0.8 & SSLR: $0.93-1.2 \mathrm{~g} \mathrm{COD} \mathrm{g}^{-1} \mathrm{VSS} \mathrm{d}^{-1}$ & [3] \\
\hline Dairy manure & UASB & $16.5-20.4$ & 7.4 & $36-48$ & $9-12.7$ & $76.5-83.4$ & - & - & $\begin{array}{l}\text { - Methane yield: } 0.296-0.312 \mathrm{~L} \mathrm{CH}_{4} \mathrm{~g}^{-1} \mathrm{COD} \\
\text { - Higher values corresponded to UASB with } \\
\text { polymer addition }\end{array}$ & {$[34]$} \\
\hline $\begin{array}{c}\text { Dairy } \\
\text { wastewater }\end{array}$ & $\mathrm{AF} / \mathrm{BAF}$ & $1.8-2.4$ & $6.6-8.4$ & $18.2-38.6$ & $0.66-0.72$ & $\begin{array}{c}\text { 98-99 } \\
\text { (Overall) }\end{array}$ & - & - & $\begin{array}{l}\text { - Recirculation ratio ranged } 100 \%-300 \% \text {; } \\
\text { - Specific growth rate of the integrated } \\
\text { biomass: } 0.621-1.208 \mathrm{~d}^{-1}\end{array}$ & [39] \\
\hline $\begin{array}{c}\text { Distillery } \\
\text { vinasse }\end{array}$ & UASFB & $3.1-21.7$ & $6-6.5$ & $25-27$ & $17.9-18.2$ & $80-82$ & $84-87$ & $<0.4$ & SSLR: $0.43-0.47 \mathrm{~g} \mathrm{COD} \mathrm{g}^{-1} \mathrm{VS} \mathrm{d}^{-1}$ & [29] \\
\hline $\begin{array}{c}\text { Food } \\
\text { processing }\end{array}$ & JBILAFB & $0.96-7.9$ & $3.4-11.2$ & 24 & $1.6-5.6$ & 80 & - & $0.2-0.5$ & $\begin{array}{l}\text { - Methane production: } 0.414 \mathrm{~m}^{3} \mathrm{~L}^{-1} \text { reactor } \\
\text { volume day }{ }^{-1} \text {; } \\
\text { - Specific energy input for the anaerobic } \\
\text { reactor: } 0.12 \mathrm{kWh} \mathrm{m}^{-3}\end{array}$ & {$[11]$} \\
\hline $\begin{array}{l}\text { Cassava starch } \\
\text { wastewater }\end{array}$ & UMAR & 10.5 & $4.5-4.92$ & 6 & $10.2-40$ & $77.5-92$ & - & - & $\begin{array}{l}\text { - The optimum HRT was } 6.0 \mathrm{~h} \text { at influent COD } \\
\text { of } 4000 \mathrm{mg} \mathrm{L}^{-1} \text {; } \\
\text { - Specific methanogenic activity: } 0.31 \text { and } \\
0.73 \mathrm{~g} \mathrm{COD}_{\mathrm{CH} 4} \mathrm{~g}^{-1} \mathrm{VSS} \mathrm{d}^{-1} \text { for the first and } \\
\text { second feed }\end{array}$ & {$[20]$} \\
\hline $\begin{array}{c}\text { Olive mill } \\
\text { effluent }\end{array}$ & UMAR & $5-48$ & $\sim 7$ & $240-120$ & $5-48$ & $81-87$ & - & - & Maximum biogas production: $1.4 \mathrm{~m}^{3} \mathrm{~m}^{-3} \mathrm{~d}^{-1}$ & [19] \\
\hline
\end{tabular}

Notes: ${ }^{a}$ UAF: upflow anaerobic filter; FBR: anaerobic fixed bed reactor; UASB: upflow anaerobic sludge blanket reactor; AF/BAF: integrated anaerobic/aerobic filter system; UASFB: hybrid upflow anaerobic sludge-filter bed reactor; JBILAFB: full-scale jet biogas internal loop anaerobic fluidized bed; UMAR: upflow multistage anaerobic reactor; TCOD: total chemical oxygen demand; HRT: hydraulic retention time; OLR: organic loading rates; SCOD: soluble chemical oxygen demand; VFA: volatile fatty acids; VSS: volatile suspended solids; VS: volatile solids. 


\section{Specific Design and Operational Considerations}

Within the high rate anaerobic treatment technologies, the immobilization of the microorganisms in the fixed bed reactors and the formation of the granules in UASB have been recognized as the two most frequently used anaerobic techniques to reduce the HRT during the anaerobic digestion of wastewater having low organic matter concentration [1,21]. The upflow fixed bed and UASB reactors are discussed in the subsequent sections.

\subsection{Upflow Fixed Bed Reactors}

The upflow fixed bed reactors or upflow anaerobic filter (UAF) is one of the earlier designs, and its characteristics are well defined $[3,22,40]$. The UAF is a relatively simple technology; and in engineering terms, it is not as complex as fluidized bed reactors, and in biological terms, it does not require the formation of a granular sludge, a prerequisite for the UASB reactor, which is usually very difficult to maintain. Also, fixed-film processes are inherently stable and resistant to organic and hydraulic shock loading conditions [6]. Since there is no provision made for intentional wastage of excess biomass from the filters similar to UASB reactors, clogging occurs with continued operation [1].

To accommodate the accumulation of non-attached biomass without plugging of the bed, the early designs of low voidage, rock-packed reactors have largely been replaced by systems that incorporate synthetic packing materials [6,41]. The microorganisms' immobilization on surfaces of synthetic carrier material is an increasingly used strategy to enhance biological treatment. The preferable features of the immobilized cells in comparison to the non-immobilized counterparts includes lower sensitivity to toxic loads, greater catalytic stability, longer microbial residence time, more tolerance to oligotrophic conditions and lower biomass washout risk [42,43].

Nikolaeva et al. [40] used waste tire rubber and zeolite as microorganism immobilization supports; Fia et al. [6] used blast furnace cinders, polyurethane foam and crushed stone as the supporting materials with porosities of $53 \%, 95 \%$ and $48 \%$, respectively. Other materials that have been utilized for the adhesion of biomass included brick ballasts [44], Raschig rings $(1.2 \mathrm{~cm}$ diameter $\times 1.2 \mathrm{~cm})$ [45], low and high-density polyethylene media [3,22,35,41], polypropylene pall rings [46], non-woven disks [47], porous polyurethane foam [48] and modified porphyritic andesite (WRS) as ammonium adsorbent and bed material [49]. Rajagopal [1] suggested the unclogging procedures with fluidization by gas re-circulation or using liquid, which can be applied whenever clogging occurs. Such a problem can also be overcome by using UAF filled ( $80 \%$ or lower by volume) with low-density floating media [22]. Recently, biofilm reactors have also attracted more attention, especially for treatment of wastewaters containing bio-recalcitrant, inhibitory and toxic compounds [50,51]. However, there is a necessity of (i) post-treatment to reach the discharge standards for organic matter, nutrients (e.g., $\mathrm{NH}_{4}{ }^{+}, \mathrm{PO}_{4}{ }^{3-}, \mathrm{S}^{2}$ ) and pathogens; and (ii) purification of biogas [22,52].

\subsection{UASB Reactors}

The chief characteristics of a UASB reactor that makes it the established high-rate anaerobic digester worldwide (particularly in tropical countries) is the availability of granular or flocculent sludge, allowing it to achieve high organic matter (COD) removal efficiencies without the need of a 
support material $[21,34,52,53]$; the natural turbulence caused by the rising gas bubbles enhances the reactor content mixing and provides efficient wastewater and biomass contact. Therefore, mechanical mixing is not required, thus significantly reducing the energy demand and its associated cost.

Nevertheless, there are still unresolved issues in the anaerobic treatment technology. One of the major drawbacks of these reactors has been the requirement of a long solids retention time, which is not associated with the increasing volume of sludge produced from industrial and human activities [21]. Garcia et al. [34] listed various factors affecting granulation and, then, efficiency in UASB reactors viz. composition and concentration of organic matter in wastewater to be treated, operating temperature, $\mathrm{pH}$, high ammonia nitrogen concentrations, presence of polyvalent cations, hydrodynamic conditions, inoculated seed and the production of exo-cellular polymeric substances by anaerobic bacteria. Rajagopal et al. [29] mentioned that with poor sedimentation characteristics in high loaded anaerobic reactors with suspended solids, the active biomass can be washed out from the reactor with the effluent, causing digester instability. Other drawbacks have been the long start-up period, flotation and disintegration of granular sludge, sludge bulking, deterioration of performance at low temperatures, high sulfate concentration, impure biogas and insufficient removal of organic matters, pathogens and nutrients in the final effluent, thereby failing to comply with the local standards for discharge or reuse [39,52,54,55].

\subsection{Integrated Approach: Modified Configurations and Combined Systems}

The researchers have been trying to find out new technologies to enhance the performance of anaerobic digesters, especially on the effluent quality, start up and biogas purification, in order to develop a global sustainable wastewater treatment technology. Rajagopal et al. [29] proposed the hybrid upflow anaerobic sludge-filter bed (UASFB) reactors, in which the filter bed is located above the sludge bed zone, to reduce the risk of biomass washout from the reactor, especially at high loading rates. This configuration also improved the hydrodynamics characteristics by minimizing the clogging and short circuiting problems inside the reactors.

Lim and Fox [39] developed an anaerobic/aerobic filter (AF/BAF) system for the treatment of dairy wastewater, primarily to remove organic matter and nitrogen simultaneously. The influent was blended with recirculated effluent $(100 \%-300 \%)$ to allow for pre-denitrification in the AF, followed by nitrification in the BAF. The average COD removal efficiency was $79.8 \%-86.8 \%$ in the $\mathrm{AF}$, and the average total nitrogen removal efficiency was $50.5 \%-80.8 \%$ in the AF/BAF system. They have concluded that linear velocity was a critical parameter to determine sloughing of biomass in the AF.

Huang et al. [56] studied the mesophilic two-phase anaerobic system for the treatment of maize ethanol wastewater, particularly in terms of start-up, cultivation and the morphology of mature granular sludge in an improved methanogenic UASB reactor. By gradually increasing volumetric loading rate and regulating internal circulation, the UASB reactor developed bigger size granules (more than $1.3 \mathrm{~mm}$ ), and hence, a quick start-up was achieved. They observed that the microfloras of mature methanogenic granular sludge were mainly Brevibacterium and filamentous bacteria.

A three-phase separator configuration increased the COD removal by $20 \%$, biogas yield by $29 \%$ and decreased biomass wash out by $25 \%$ in an UASB treating fruit canning wastewater [57]. An intermittent feeding strategy at an OLR of $4.8 \mathrm{~g} \mathrm{COD} \mathrm{L}^{-1} \mathrm{~d}^{-1}$ of olive mill wastewater applied to an 
inverted anaerobic sludge blanket (IASB) reactor improved long chain fatty acids mineralization, prevented biomass washout and yielded $1.4 \mathrm{~m}^{3} \mathrm{CH}_{4} \mathrm{~m}^{-3} \mathrm{~d}^{-1}$ [19]. Diez et al. [58] reported that an anaerobic membrane bioreactor (AnMBR) removed 97\% of the COD of oil and greasy wastewater (COD of $22 \mathrm{~g} \mathrm{~L}^{-1}$ ) at an OLR of $5.1 \mathrm{~kg} \mathrm{COD} \mathrm{m}^{-3} \mathrm{~d}^{-1}$. Kim et al. [59] implemented a high-rate two-phase system $\left(\mathrm{OLR}=6.5 \mathrm{~g} \mathrm{COD} \mathrm{L}^{-1} \mathrm{~d}^{-1}\right)$ of an anaerobic sequencing batch reactor (ASBR) and an upflow anaerobic sludge blanket (UASB) reactor in series to treat synthetic dairy wastewater treatment. The overall lipid and COD removals were about $80 \%$.

A three-stage configuration of a pre-acidification tank and sequential upflow anaerobic sludge bed reactors (UASBRs) at OLRs of 2.8-7 $\mathrm{g} \mathrm{COD} \mathrm{L}^{-1} \mathrm{~d}^{-1}$ has been used to treat raw cheese whey with an effluent recycling achieved COD removal of 50\%-92\% and fat removal of $63 \%-89 \%$ [60]. An upflow anaerobic packed bed (UAPB) reactor filled with seashell treated cheese whey at OLRs of 1.6 to $9.9 \mathrm{~g}$ COD L ${ }^{-1} \mathrm{~d}^{-1}$, and HRTs of 6-24 h at $25^{\circ} \mathrm{C}$ removed 95\% of COD [61].

In order to upgrade the quality of anaerobically treated effluent to a level recommended for irrigation, Yasar and Tabinda [62] integrated the UASB reactor with UV and AOPs (advanced oxidation processes) (Ozone, $\mathrm{H}_{2} \mathrm{O}_{2} / \mathrm{UV}$, Fenton and photo-Fenton) primarily for complete color and COD removal and disinfection of pathogens.

\section{Mass Transfer Considerations}

Rajagopal [1] described that substrate mass transfer into biomass occurs most rapidly when the bio-particle surface-to-volume ratio is high. According to that research, the suspended growth anaerobic processes generate relatively small bio-particles with optimal surface-to-volume ratios. Fixed film or attached growth reactors are often considered to be susceptible to bio-film surface area limitations. In this respect, Chen et al. [63] concluded that the bed expansion ratio of a super-high rate anaerobic bioreactor correlated positively with superficial gas and liquid velocities, while maximum bed sludge content and maximum bed contact time between sludge and liquid correlated negatively. Ganesh et al. [3] addressed the effect of media design on treatment performance and stated that physical parameters, like the type of media, its size and shape, affect the performance of waste treatment. Chen et al. [64] modeled the dynamic behavior and concentration distribution of granular sludge in a super-high-rate spiral anaerobic bioreactor (SSAB) and found that these two parameters depend on the ecological environment of microbial communities and substrate degradation efficiency along the bed's height. The sludge transport efficiency of up-moving biogas in SSAB is less than that in a UASB reactor. Yang et al. [65] analyzed the mass transfer in tubular membrane anaerobic bioreactors operated under gas-lift two-phase flow using fluid dynamic modeling. They found that the results with water were in contrast to those with sludge. The sludge filterability strongly influences the transmembrane pressure, and there is a difference between the mass transfer capacity at the noses and the tails of the gas bubbles. Feng et al. [66] reported a rapid-mass transfer in a fluidized bed reactor using brick particles as carrier materials; at increasing OLRs from 7.37 to $18.52 \mathrm{~kg} \mathrm{COD} \mathrm{m}^{-3} \mathrm{~d}^{-1}$ and HRT of $8 \mathrm{~h}$, COD removals between $65 \%$ and $75 \%$ was obtained. To minimize non-idealities in reactor hydraulics, most anaerobic reactor designs utilize proprietary systems for enhancing process mixing. Anaerobic contact systems rely on mechanical or gas recirculation systems that must be properly sized for the specific application [1]. 


\section{Energy Production Estimation}

The production of a useful and valuable product during agro-food wastewater treatment, such as hydrogen and/or methane, could help to lower treatment costs [1,67]. Using a single-chamber microbial electrolysis cell with a graphite-fiber brush anode, Wagner et al. [67] generated hydrogen gas at the rate of $0.9-1.0 \mathrm{~m}^{3} \mathrm{~m}^{-3} \mathrm{day}^{-1}$ using a full-strength or diluted swine wastewater. Under the best conditions, the specific hydrogen production rate of $270 \mathrm{~mL} \mathrm{H}_{2} \mathrm{~g}^{-1} \mathrm{MLVSS} \mathrm{d}^{-1}$ (or $3310 \mathrm{~mL} \mathrm{H}_{2} \mathrm{~L}^{-1} \mathrm{~d}^{-1}$ ) and a hydrogen yield of $172 \mathrm{~mL} \mathrm{H}_{2} \mathrm{~g}^{-1} \mathrm{COD}$ removed were obtained for the treatment of alcohol distillery wastewater containing high potassium and sulfate in an anaerobic sequencing batch reactor [68].

Nieto et al. [7] obtained methane yields ranging from 202 to $549 \mathrm{~mL} \mathrm{CH}_{4} \cdot \mathrm{gVS}_{\mathrm{fed}}{ }^{-1}$ at standard temperature and pressure (STP) from six wastes (beverage waste, milled apple waste, milk waste, yogurt waste, fats and oils (F\&O) from dairy wastewater treatment, F\&O and cattle manure). They reported that methane content in biogas ranged from 58\% to 76\%. Rajagopal et al. [69] developed a process combining anaerobic digestion and anoxic/oxic treatment to treat swine wastewater and obtained $5.9 \mathrm{Nm}^{3}$ of $\mathrm{CH}_{4} \mathrm{~m}^{-3}$ of slurry added. In another study, Labatut et al. [70] observed that co-digestion of dairy manure with easily-degradable substrates increases the specific methane yields when compared to manure-only. For instance, co-digestion of dairy manure with used oil (ratio: 75:25 on volatile solids basis) produced more methane yield $\left(361 \mathrm{Nm}^{3}\right.$ ton $\left.^{-1} \mathrm{VS}_{\text {added }}\right)$ than dairy manure with cheese whey (ratio: 75:25 on VS basis; methane yield: $252 \mathrm{Nm}^{3} \operatorname{ton}^{-1} \mathrm{VS}_{\text {added }}$ ). Ogejo and Li [71] obtained a biogas yield ranging from 0.072 to $0.8 \mathrm{~m}^{3} \mathrm{~g}^{-1} \mathrm{VS}$ (methane content ranging from $56 \%$ to $70 \%$ ) by co-digesting flushed dairy manure and turkey processing wastewater. The biogas produced was enough to run a $50 \mathrm{~kW}$ generator to produce electricity for about 5.5 and $9 \mathrm{~h}$ for the 1:1 and 1:2 feed mixtures. In addition to the electricity to be produced, other possible revenues, such as carbon credits, renewable energy credits, green tags for electricity, putting a value to the environmental benefits of anaerobic digestion or subsidies from grants or other incentives programs to make the system economically viable should be considered. On average, $18.5-40 \mathrm{~kg}$ of VS added in to the anaerobic digestion system can produce a biogas yield of $10 \pm 5 \mathrm{~m}^{3}$, when $65 \% \mathrm{VS}$ removal is achieved [72]. This indicates a daily electricity generation of $12.5-33.6 \mathrm{kWh}$ from biogas, on the assumption that the generator efficiency is $35 \%-50 \%$. In addition, a daily heat energy profit of 17.8-46.5 kWh from biogas can be estimated. One cubic meter of biogas obtained while co-digesting dairy manure and animal fat is equivalent to $20 \mathrm{MJ}$ of heat energy [73]. When used as fuel for a co-generator, $1 \mathrm{~m}^{3}$ of biogas can produce $1.7 \mathrm{kWh}$ of electricity and $7.7 \mathrm{MJ}$ of heat. In addition to co-digestion, Esposito et al. [74] suggested several pre-treatment techniques that can be applied to increase further the biogas production, such as mechanical comminution, solid-liquid separation, bacterial hydrolysis and alkaline addition at high temperature, ensilage, alkaline, ultrasonic and thermal pre-treatments.

\section{Toxicity}

Sodium toxicity is a common problem causing inhibition of anaerobic digestion. Digesters treating highly concentrated wastes, such as food and concentrated animal manure, are likely to suffer from partial 
or complete inhibition of methane-producing consortia, including methanogens [75,76]. Zhao et al. [10] confirmed that organofluorine compounds, such as 4-fluorophenol (p-FP), 4-fluorobenzoic acid (p-FB) and 4-fluoroaniline (p-FA), have a potential toxicity on methanogenesis and biodegradability. Procházka et al. [77] described that high ammonia nitrogen concentration (especially the unionized form) (4.0 $\left.\mathrm{g} \mathrm{L}^{-1}\right)$ would inhibit methane production, while low ammonia nitrogen concentration ( $\left.0.5 \mathrm{~g} \mathrm{~L}^{-1}\right)$ could cause low methane yield, loss of biomass (as VSS) and loss of the acetoclastic methanogenic activity. Chen et al. [78] indicated that certain ions, such as $\mathrm{Na}^{+}, \mathrm{Ca}^{2+}$ and $\mathrm{Mg}^{2+}$, were found to be antagonistic to ammonia inhibition, a phenomenon in which the toxicity of one ion is decreased by the presence of other ion(s). At high concentrations, potassium, light metals ions ( $\mathrm{Na}, \mathrm{K}$, $\mathrm{Mg}, \mathrm{Ca}$ and $\mathrm{Al}$ ) and other salts can also interrupt cell function [78].

\section{Toxicity Control Strategies}

Vyrides et al. [79] indicated that glycine-betaine (GB), an organic compound, can cause antagonism against sodium toxicity. However, using GB to decrease sodium toxicity in commercial scale anaerobic digesters would be too costly [75]. Suwannoppadol et al. [75] described that when grass clippings were added at the onset of anaerobic digestion of acetate containing a sodium concentration of $7.8 \mathrm{~g} \mathrm{Na}^{+} \mathrm{L}^{-1}$, a total methane production of about $8 \mathrm{~L} \mathrm{CH}_{4} \mathrm{~L}^{-1}$ was obtained, whereas no methane was produced in the absence of grass leaves. Another way of tackling the sodium salts problem is by allowing the anaerobic sludge to acclimate to high sodium concentrations [80], but this technique requires time for the methanogens to adapt to the saline conditions, which in turn, results in a prolonged period before the anaerobic reactor can achieve its full-loading capacity. Zhao et al. [10] concluded that adsorption was the main removal mechanism for the three F-substituent aromatics, such as 4-fluorophenol (p-FP), 4-fluorobenzoic acid (p-FB) and 4-fluoroaniline (p-FA). To overcome ammonia toxicity, many strategies have been suggested: chemical precipitation, $\mathrm{pH}$ and temperature control [78]; use of carbon fiber textiles [81]; acclimation of methanogenic consortia to high ammonia levels [82]; and ammonia stripping and adjustment of the C:N ratio of feedstock [83]. Uludag-Demirer et al. [84] and Wang et al. [49] described the physical, chemical and biological methods, such as addition of ammonium-selective adsorbent, ammonium removal by forming struvite precipitation or a biological anoxic/oxic $(\mathrm{A} / \mathrm{O})$ process. Among these methods, ammonium removal by adding ammonium-selective adsorbents could be the most attractive and practical, because of its easier operation and economic impact, and the ammonium-saturated adsorbents can be further used as nitrogen fertilizer [49].

\section{Modeling Advances}

Various kinetic equations reported for anaerobic processes [3,85] generally relied on Monod's equation. Monod's equation is based on the growth rate and the substrate utilization rate during biodegradation. Wong et al. [86] determined the biological kinetic constants for a laboratory anaerobic bench scale reactors (ABSR) treating palm oil mill effluent. The investigation showed that the growth yield $\left(Y_{G}\right)$, specific biomass decay $(b)$, maximum specific biomass growth rate $\left(\mu_{\max }\right)$, saturation constant $\left(K_{s}\right)$ and critical retention time $\left(\Theta_{c}\right)$ were in the range of $0.990 \mathrm{~g} \mathrm{VSS} \mathrm{g}^{-1} \mathrm{COD}_{\text {removed }} \mathrm{d}^{-1}$, $0.024 \mathrm{~d}^{-1}, 0.524 \mathrm{~d}^{-1}, 203.433 \mathrm{~g} \mathrm{COD} \mathrm{L}^{-1}$ and $1.908 \mathrm{~d}$, respectively. 
Fuzzato et al. [26] used simplified first-order kinetics for modeling a mesophilic anaerobic sequencing batch biofilm reactor (ASBBR) treating lipid-rich wastewater. Nikolaeva et al. [40] also observed that a first-order kinetic model described the experimental results obtained for the upflow fixed bed digesters treating dairy manure well. In addition, they also concluded that the first-order model was adequate for assessing the effect of HRT on the removal efficiency and methane production. Ganesh et al. [3] used a modified Stover-Kincannon kinetic model to predict the performance of anaerobic fixed bed reactors treating winery wastewater. In a similar study, Rajagopal et al. [87] applied bio-kinetic models, such as the modified Stover-Kincannon and second-order kinetic models for the upflow anaerobic filters treating high strength fruit canning and cheese dairy wastewaters. Fia et al. [6] also used the modified Stover-Kincannon and second-order kinetic models for the experimental data obtained from the upflow anaerobic fixed bed reactors treating coffee bean processing wastewater. Abdurahman et al. [85] employed kinetic equations from Monod, Contois and Chen and Hashimoto to describe the kinetics of palm oil mill effluent (POME) treatment in a membrane anaerobic system (MAS) at organic loading rates ranging from 1 to $11 \mathrm{~kg} \mathrm{COD} \mathrm{m}^{-3} \mathrm{~d}^{-1}$. Kaewsuk et al. [88] conducted a pilot scale experiment to investigate the performance of the membrane sequencing batch reactor (MSBR) treating dairy wastewater and checked the suitability of the kinetics for an engineering design. The kinetic coefficients $K_{s}, k, k_{d}, Y$ and $m m$ were found to be 174-mg COD L ${ }^{-1}, 7.42 \mathrm{~d}^{-1}, 0.1383 \mathrm{~d}^{-1}, 0.2281 \mathrm{~d}^{-1}$ and $1.69 \mathrm{~d}^{-1}$, respectively.

Recently, there has been a move by the International Water Association's (IWA) Task Group for Mathematical Modeling of Anaerobic Digestion Processes to develop a common model called Anaerobic Digestion Model No. 1 (ADM1) that can be used by researchers and practitioners [89,90]. Lee et al. [91] examined the application of the ADM1 for mathematical modeling of anaerobic process using a lab-scale temperature-phased anaerobic digestion (TPAD) process. Sensitivity analysis showed

that $k_{m \text {.process }}$ (maximum specific uptake rate) and $K_{\text {S.process }}$ (half saturation value) had high sensitivities to model components. They have concluded that simulation with estimated parameters showed good agreement with experimental results in the case of methane production, uptake of acetate, soluble (SCOD) and total chemical oxygen demand (TCOD). The structure and properties of a microbial community may be influenced by process operation and, in their turn, also determine the reactor functioning. In order to adequately describe these phenomena, Ramirez et al. [89] emphasized that mathematical models need to consider the underlying microbial diversity. In order to demonstrate this contribution, they have extended the ADM1 to describe microbial diversity between organisms of the same functional group. Boubaker and Ridha [92] used the ADM1 model to simulate the mesophilic anaerobic co-digestion of olive mill wastewater (OMW) with olive mill solid waste (OMSW). The results indicated that the ADM1 model could simulate with good accuracy: gas flows, methane and carbon-dioxide contents, $\mathrm{pH}$ and total volatile fatty acids (TVFA) concentrations of effluents for various feed concentrations digested at different HRTs and especially at HRTs of 36 and 24 days. Furthermore, effluent alkalinity and ammonium nitrogen were also successfully predicted.

\section{Technology Assessments}

Onsite industrial wastewater anaerobic treatment requires systems with a significant capital cost and incur increasing expenses for successful long-term operation, control and maintenance. Farhan [93] 
evaluated a high-rate digestion system for brewery wastewater technically and economically. The technical evaluating criteria consist of, among commonly used engineering design criteria, such as hydraulic and organic loading rates, wastewater characteristics and layout and space requirements, factors that reflect the dynamics of technology development. The abilities of the anaerobic high rate bioreactors to meet the regulatory requirements reliably with flexibility for future upgrading are some of the technical evaluating factors [93]. The energy savings and renewable energy credits are among the economical assessment criteria [93].

Gebrezgabher et al. [94] analyzed the economic performance of anaerobic digestion of a biogas plant using the net present value (NPV) and internal rate of return (IRR). They conclude that the uncertainty of the increasingly tightened regulations regarding the effluent of anaerobic treatment, the quality and value of the digestate and the high investment and operating costs limit the on-farm applications of anaerobic digestion of agro wastes.

\section{Summary and Conclusions}

A critical analysis of the literature reveals that there is a strong possibility and need to enhance the performance of high rate anaerobic biogas reactors. This technique has many advantages over other conventional methods. However, the challenges associated with the digester operation at lower HRT and higher OLR need to be addressed, which include biomass washout, clogging, short-circuiting, process inhibitions, poor final effluent and biogas quality. Different materials (polyethylene, polypropylene pall rings, polyurethane foam, carbon felt and waste tire rubber) had been tried as packing material in the anaerobic fixed bed reactors, depending upon their availability and other specifications, such as material properties, cost, etc. These packing materials would help to reduce hydraulic retention time, which in turn lessens the required volume of the reactor, and ultimately, the cost could be reduced. The practical aspects of using pure microbial film as magnifying microbial layers should be looked into. In the case of UASB reactors, the following important aspects should be looked into: (i) enhancing the start-up and granulation in UASB reactors; (ii) coupling with post-treatment unit to overcome the temperature constraint; and (iii) improving the removal efficiencies of the organic matter, nutrients and pathogens in the final effluent.

When talking about toxicity, there are many soluble organic and inorganic materials that can be either stimulatory or inhibitory. A good example of this is the effect of ammonia nitrogen on the anaerobic digestion process. When potential inhibitory materials are slowly increased within the environment, many biological organisms can rearrange their metabolic resources, thus overcoming the metabolic block produced by the normally inhibitory material. Under shock load conditions, sufficient time is not available for this rearrangement to take place. Finally, there is the possibility of antagonism and synergism effects of using different organic wastes as co-substrates. Antagonism is defined as a reduction of the toxic effect of one substance by the presence of another. Synergism is defined as an increase in the toxic effect of one substance by the presence of another. This is an important consideration when designing for potential cation toxicity. Additional research efforts are essential to get more insight about the stable performance of the digesters against various process inhibitors, such as ammonia, sodium, sulfur, etc. While lessening the economic losses, vigilant substrate management and early detection of inhibitions are critical. 


\section{References}

1. Rajagopal, R. Treatment of Agro-Food Industrial Wastewaters Using UAF and Hybrid UASB-UAF Reactors. Ph.D. Thesis, Indian Institute of Technology Roorkee, Roorkee, India, 2008.

2. Badshah, M.; Parawira, W.; Mattiasson, B. Anaerobic treatment of methanol condensate from pulp mill compared with anaerobic treatment of methanol using mesophilic UASB reactors. Bioresour. Technol. 2012, 125, 318-327.

3. Ganesh, R.; Rajagopal, R.; Torrijos, M.; Thanikal, J.M.; Ramanujam, R. Anaerobic treatment of winery wastewater in fixed bed reactors. Bioprocess Biosyst. Eng. 2010, 33, 619-628.

4. Meksi, N.; Haddar, W.; Hammami, S.; Mhenni, M.F. Olive mill wastewater: A potential source of natural dyes for textile dyeing. Ind. Crops Prod. 2012, 40, 103-109.

5. MPOC (Malaysian Palm Oil Council). Available online: http://www.mpoc.org.my (accessed on 5 March 2013).

6. Fia, R.L.; Matos, A.T.; Borges, A.C.; Fia, R.; Cecon, P.R. Treatment of wastewater from coffee bean processing in anaerobic fixed bed reactors with different support materials: Performance and kinetic modeling. J. Environ. Manag. 2012, 108, 14-21.

7. Nieto, P.P.; Hidalgo, D.; Irusta, R.; Kraut, D. Biochemical methane potential (BMP) of agro-food wastes from the Cider Region (Spain). Water Sci. Technol. 2012, 66, 1842-1848.

8. Veronafiere (Ente Autonomo per le Fiere di Verona). Vinitaly analysis. Worldwide Wine: The Sector Scenario, Production, Consumption and Trade on a World Scale under the Magnifying Glass at Vinitaly. Available online: http://www.vinitaly.com/pdf/cartellaStampa/ 5gbCsVinitaly12_SituazioneMondoItalia_23marzo.pdf (accessed on 5 March 2013).

9. Un, U.T.; Altay, U.; Koparal, A.S.; Ogutveren, U.B. Complete treatment of olive mill wastewaters by electrooxidation. Chem. Eng. J. 2008, 139, 445-452.

10. Zhao, Z.-Q.; Xu, L.-L.; Li, W.-B.; Wang, M.-Z.; Shen, X.-L.; Mae, G.-S.; Shena, D.-S. Toxicity of three F-substituent aromatics in anaerobic systems. J. Chem. Technol. Biotechnol. 2012, 87, 1489-1496.

11. Wei, C.; Zhang, T.; Feng, C.; Wu, H.; Deng, Z.; Wu, C.; Lu, B. Treatment of food processing wastewater in a full-scale jet biogas internal loop anaerobic fluidized bed reactor. Biodegradation 2011, 22, 347-357.

12. Rupani, P.F.; Singh, R.P.; Ibrahim, M.H.; Esa, N. Review of current palm oil mill effluent (POME) treatment methods: Vermicomposting as a sustainable practice. World Appl. Sci. J. 2010, 10, 1190-1201.

13. Alkaya, E.; Demirer, G.N. Anaerobic acidification of sugar-beet processing wastes: Effect of operational parameters. Biomass Bioenergy 2011, 35, 32-39.

14. Gotmare, M.; Dhoble, R.M.; Pittule, A.P. Biomethanation of dairy waste water through UASB at mesophilic temperature range. Int. J. Adv. Eng. Sci. Technol. 2011, 8, 1-9. 
15. Ersahin, M.E.; Ozgun, H.; Dereli, R.K.; Ozturk, I. Anaerobic treatment of industrial effluents: An overview of applications. In Waste Water-Treatment and Reutilization; Einschlag, F.S.G., Ed.; InTech: New York, NY, USA, 2011; Available online: http://www.intechopen.com/books/wastewater-treatment-and-reutilization/anaerobic-treatment-of-industrial-effluents-an-overview-ofapplications (accessed on 5 March 2013).

16. Senturk, E.; Ince, M.; Engin, O.G. Treatment efficiency and VFA composition of a thermophilic anaerobic contact reactor treating food industry wastewater. J. Hazard. Mater. 2010, 176, 843-848.

17. Ersahin, M.E.; Dereli, R.K.; Ozgun, H.; Donmez, B.G.; Koyuncu, I.; Altinbas, M.; Ozturk, I. Source based characterization and pollution profile of a baker's yeast industry. Clean-Soil Air Water 2011, 39, 543-548.

18. Passeggi, M.; Lopez, I.; Borzacconi, L. Integrated anaerobic treatment of dairy industrial wastewater and sludge. Water Sci. Technol. 2009, 59, 501-506.

19. Gonçalves, M.R.; Costa, J.C.; Marques, I.P.; Alves, M.M. Strategies for lipids and phenolics degradation in the anaerobic treatment of olive mill wastewater. Water Res. 2012, 46, 1684-1692.

20. Sun, L.; Wan, S.; Yu, Z.; Wang, Y.; Wang, S. Anaerobic biological treatment of high strength cassava starch wastewater in a new type up-flow multistage anaerobic reactor. Bioresour. Technol. 2012, 104, 280-288.

21. Chong, S.; Sen, T.K.; Kayaalp, A.; Ang, H.M. The performance enhancements of upflow anaerobic sludge blanket (UASB) reactors for domestic sludge treatment-A State-of-the-art review. Water Res. 2012, 46, 3434-3470.

22. Rajagopal, R.; Ganesh, R.; Escudie, R.; Mehrotra, I.; Kumar, P.; Thanikal, J.V.; Torrijos, M. High rate anaerobic filters with floating supports for the treatment of effluents from small-scale agro-food industries. Desalin. Water Treat. 2009, 4, 183-190.

23. Esparza, S.M.; Solís, M.C.; Herná, J.J. Anaerobic treatment of a medium strength industrial wastewater at low-temperature and short hydraulic retention time: A pilot-scale experience. Water Sci. Technol. 2011, 64, 1629-1635.

24. Shastry, S.; Nandy, T.; Wate, S.R.; Kaul, S.N. Hydrogenated vegetable oil industry wastewater treatment using UASB reactor system with recourse to energy recovery. Water Air Soil Pollut. 2010, 208, 323-333.

25. Won, S.G.; Lau, A.K. Effects of key operational parameters on biohydrogen production via anaerobic fermentation in a sequencing batch reactor. Bioresour. Technol. 2011, 102, 6876-6883.

26. Fuzzato, M.C.; Tallarico Adorno, M.A.; de Pinho, S.C.; Ribeiro, R.; Tommaso, G. Simplified mathematical model for an anaerobic sequencing batch biofilm reactor treating lipid-rich wastewater subject to rising organic loading rates. Environ. Eng. Sci. 2009, 26, 1197-1206.

27. Shanmugam, A.S.; Akunna, J.C. Comparing the performance of UASB and GRABBR treating low strength wastewaters. Water Sci. Technol. 2008, 58, 225-232.

28. Bialek, K.; Kumar, A.; Mahony, T.; Lens, P.N.L.; Flaherty, V.O. Microbial community structure and dynamics in anaerobic fluidized-bed and granular sludge-bed reactors: Influence of operational temperature and reactor configuration. Microb. Biotechnol. 2012, 5, 738-775. 
29. Rajagopal, R.; Mehrotra, I.; Kumar, P.; Torrijos, M. Evaluation of a hybrid upflow anaerobic sludge-filter bed reactor: Effect of the proportion of packing medium on performance. Water Sci. Technol. 2010, 61, 1441-1450.

30. Gnansounou, E. Production and use of lignocellulosic bioethanol in Europe: Current situation and perspectives. Bioresour. Technol. 2010, 101, 4842-4850.

31. Nkemka, V.N.; Murto, M. Biogas production from wheat straw in batch and UASB reactors: The roles of pretreatment and seaweed hydrolysate as a co-substrate. Bioresour. Technol. 2013, 128, 164-172.

32. Alvira, P.; Tomás-Pejó, E.; Ballesteros, M.; Negro, M.J. Pretreatment technologies for an efficient bioethanol production process based on enzymatic hydrolysis: A review. Bioresour. Technol. 2010, 101, 4851-4861.

33. Bosco, F.; Chiampo, F. Production of polyhydroxyalcanoates (PHAs) using milk whey and dairy wastewater activated sludge Production of bioplastics using dairy residues. J. Biosci. Bioeng. 2010, 109, 418-421.

34. Garcia, H.; Rico, C.; Garcia, P.A.; Rico, J.L. Flocculants effect in biomass retention in a UASB reactor treating dairy manure. Bioresour. Technol. 2008, 99, 6028-6036.

35. Yu, Y.-C.; Gao, D.-W.; Tao, Y. Anammox start-up in sequencing batch biofilm reactors using different inoculating sludge. Appl. Microbiol. Biotechnol. 2012, doi:10.1007/s00253-012-4427-z.

36. Zhang, T.; Yan, Q.M.; Ye, L. Autotrophic biological nitrogen removal from saline wastewater under low DO. J. Chem. Technol. Biot. 2010, 85, 1340-1345.

37. Hendrickx, T.L.G.; Wang, Y.; Kampman, C.; Zeeman, G.; Temmink, H.; Buisman, C.J.N. Autotrophic nitrogen removal from low strength waste water at low temperature. Water Res. 2012, 46, 2187-2193.

38. Dosta, J.; Fernandez, I.; Vazquez-Padin, J.R.; Mosquera-Corral, A.; Campos, J.L.; Mata-Alvarez, J.; Mendez, R. Short- and long-term effects of temperature on the anammox process. J. Hazard. Mater. 2008, 154, 688-693.

39. Lim, S.J.; Fox, P. A kinetic analysis and experimental validation of an integrated system of anaerobic filter and biological aerated filter. Bioresour. Technol. 2011, 102, 10371-10376.

40. Nikolaeva, S.; Sanchez, E.; Borja, R.; Raposo, F.; Colmenarejo, M.F.; Montalvo, S.; Jiménez-Rodríguez, A.M. Kinetics of anaerobic degradation of screened dairy manure by upflow fixed bed digesters: Effect of natural zeolite addition. J. Environ. Sci. Health Part A Toxic/Hazard. Substan. Environ. Eng. 2009, 44, 146-154.

41. Koupaie, E.H.; Moghaddam, M.R.A.; Hashemi, S.H. Evaluation of integrated anaerobic/aerobic fixed-bed sequencing batch biofilm reactor for decolorization and biodegradation of azo dye Acid Red 18: Comparison of using two types of packing media. Bioresour. Technol. 2013, 127, 415-421.

42. Gómez-De Jesús, A.; Romano-Baez, F.J.; Leyva-Amezcua, L.; Juárez-Ramírez, C.; Ruiz-Ordaz, N.; Galíndez-Mayer, J. Biodegradation of 2,4,6-richlorophenol in a packed-bed biofilm reactor equipped with an internal net draft tube riser for aeration and liquid circulation. J. Hazard. Mater. 2009, 161, 1140-1149. 
43. González, A.J.; Gallego, A.; Gemini, V.L.; Papalia, M.; Radice, M.; Gutkind, G.; Planes, E.; Korol, S.E. Degradation and detoxification of the herbicide 2,4-dichlorophenoxyacetic acid (2,4-D) by an indigenous Delftia sp. strain in batch and continuous systems. Int. Biodeter. Biodegr. 2012, 66, 8-13.

44. Satyawali, Y.; Pant, D.; Singh, A.; Srivastava, R.K. Treatment of rayon grade pulp drain effluent by upflow anaerobic fixed packed bed reactor (UAFPBR). J. Environ. Biol. 2009, 30, 667-672.

45. Ahn, J.-H. Nitrogen requirement for the mesophilic and thermophilic upflow anaerobic filters of a simulated paper mill wastewater. Korean J. Chem. Eng. 2008, 25, 1022-1025.

46. Deshannavar, U.B.; Basavaraj, R.K.; Naik, N.M. High rate digestion of dairy industry effluent by upflow anaerobic fixed-bed reactor. J. Chem. Pharma. Res. 2012, 4, 2895-2899.

47. Gao, F.; Zhang, H.; Yang, F.; Qiang, H.; Zhang, G. The contrast study of anammox-denitrifying system in two non-woven fixed-bed bioreactors (NFBR) treating different low $\mathrm{C} / \mathrm{N}$ ratio sewage. Bioresour. Technol. 2012, 114, 54-61.

48. Ji, G.; Wu, Y.; Wang, C. Analysis of microbial characterization in an upflow anaerobic sludge $\mathrm{bed} /$ biological aerated filter system for treating microcrystalline cellulose wastewater. Bioresour. Technol. 2012, 120, 60-69.

49. Wang, Q.; Yang, Y.; Li, D.; Feng, C.; Zhang, Z. Treatment of ammonium-rich swine waste in modified porphyritic andesite fixed-bed anaerobic bioreactor. Bioresour. Technol. 2012, 111, $70-75$.

50. Bajaj, M.; Gallert, C.; Winter, J. Biodegradation of high phenol containing synthetic wastewater by an aerobic fixed bed reactor. Bioresour. Technol. 2008, 99, 8376-8381.

51. Farhadian, M.; Duchez, D.; Vachelard, C.D.; Larroche, C. Monoaromatics removal from polluted water through bioreactors-A review. Water Res. 2008, 42, 1325-1341.

52. Mahmoud, N. High strength sewage treatment in a UASB reactor and an integrated UASB-digester system. Bioresour. Technol. 2008, 99, 7531-7538.

53. Elangovan, C.; Sekar, A.S.S. Application of Upflow anaerobic sludge blanket (UASB) reactor process for the treatment of dairy wastewater-A review. Nat. Environ. Pollut. Technol. 2012, 11, 409-414.

54. Lew, B.; Lustig, I.; Beliavski, M.; Tarre, S.; Green, M. An integrated UASB-sludge digester system for raw domestic wastewater treatment in temperate climates. Bioresour. Technol. 2011, 102, 4921-4924.

55. Li, J.; Hu, B.; Zheng, P.; Qaisar, M.; Mei, L. Filamentous granular sludge bulking in a laboratory scale UASB reactor. Bioresour. Technol. 2008, 99, 3431-3438.

56. Huang, J.P.; Liu, L.; Shao, Y.M.; Song, H.J.; Wu, L.C.; Xiao, L. Study on cultivation and morphology of granular sludge in improved methanogenic UASB. Appl. Mechan. Mater. 2012, 209-211, 1152-1157.

57. Wongnoi, R.; Songkasiri, W.; Phalakornkule, C. Influence of a three-phase separator configuration on the performance of an upflow anaerobic sludge bed reactor treating wastewater from a fruit-canning factory. Water Environ. Res. 2007, 79, 199-207.

58. Diez, V.; Ramos, C.; Cabezas, J.L. Treating wastewater with high oil and grease content using an anaerobic membrane bioreactor (AnMBR). Filtration and cleaning assays. Water Sci. Technol. 2012, 65, 1847-1853. 
59. Kim, S.-H.; Shin, H.-S. Enhanced lipid degradation in an upflow anaerobic sludge blanket reactor by integration with an acidogenic reactor. Water Environ. Res. 2010, 82, 267-272.

60. Erdirencelebi, D. Treatment of high-fat-containing dairy wastewater in a sequential UASBR system: Influence of recycle. J. Chem. Technol. Biotechnol. 2011, 86, 525-533.

61. Najafpour, G.D.; Komeili, M.; Tajallipour, M.; Asadi, M. Bioconversion of cheese whey to methane in an upflow anaerobic packed bed bioreactor. Chem. Biochem. Eng. Q. 2010, 24, 111-117.

62. Yasar, A.; Tabinda, A.B. Anaerobic treatment of industrial wastewater by UASB reactor integrated with chemical oxidation processes: An overview. Pol. J. Environ. Stud. 2010, 19, 1051-1061.

63. Chen, X.-G.; Zheng, P.; Cai, J.; Qaisar, M. Bed expansion behavior and sensitivity analysis for super-high-rate anaerobic bioreactor. J. Zhejiang Univ. Sci. B. 2010, 11, 79-86.

64. Chen, X.G.; Zheng, P.; Qaisar, M.; Tang, C.J. Dynamic behavior and concentration distribution of granular sludge in a super-high-rate spiral anaerobic bioreactor. Bioresour. Technol. 2012, 111, 134-140.

65. Yang, J.; Vedantam, S.; Spanjers, H.; Nopens, I.; van Lier, J.B. Analysis of mass transfer characteristics in a tubular membrane using CFD modeling. Water Res. 2012, 46, 4705-4712.

66. Feng, Y.; Lu, B.; Jiang, Y.; Chen, Y.; Shen, S. Anaerobic degradation of purified terephthalic acid wastewater using a novel, rapid mass-transfer circulating fluidized bed. Water Sci. Technol. 2012, 65, 1988-1993.

67. Wagner, R.C.; Regan, J.M.; Oh, S.E.; Zuo, Y.; Logan, B.E. Hydrogen and methane production from swine wastewater using microbial electrolysis cells. Water Res. 2009, 43, 1480-1488.

68. Searmsirimongkol, P.; Rangsunvigit, P.; Leethochawalit, M.; Chavadej, S. Hydrogen production from alcohol distillery wastewater containing high potassium and sulfate using an anaerobic sequencing batch reactor. Int. J. Hydrog. Energ. 2011, 36, 12810-12821.

69. Rajagopal, R.; Rousseau, P.; Bernet, N.; Béline, F. Combined anaerobic and activated sludge anoxic/oxic for piggery wastewater treatment. Bioresour. Technol. 2011, 102, 2185-2192.

70. Labatut, R.A.; Angenent, L.T.; Scott, N.R. Biochemical methane potential and biodegradability of complex organic substrates. Bioresour. Technol. 2011, 102, 2255-2264.

71. Ogejo, J.A.; Li, L. Enhancing biomethane production from flush dairy manure with turkey processing wastewater. Appl. Energ. 2010, 87, 3171-3177.

72. Rajagopal, R.; Lim, J.W.; Mao, Y.; Chen, C.L.; Wang, J.Y. Anaerobic co-digestion of source segregated brown water (feces-without-urine) and food waste: For Singapore context. Sci. Total Environ. 2013, 443, 877-886.

73. Alberta Agriculture and Rural Development. Economic Feasibility of Anaerobic Digesters; Department of Agriculture and Rural Development: Edmonton, AB, Canada, 2008; Available online: http://www1.agric.gov.ab.ca/\$department/deptdocs.nsf/all/agdex12280 (accessed on 5 March 2013).

74. Esposito, G.; Frunzo, L.; Giordano, A.; Liotta, F.; Panico, A.; Pirozzi, F. Anaerobic co-digestion of organic wastes. Rev. Environ. Sci. Biotechnol. 2012, 11, 325-341. 
75. Suwannoppadol, S.; Ho, G.; Cord-Ruwisch, R. Overcoming sodium toxicity by utilizing grass leaves as co-substrate during the start-up of batch thermophilic anaerobic digestion. Bioresour. Technol. 2012, 125, 188-192.

76. Hierholtzer, A.; Akunna, J.C. Modelling sodium inhibition on the anaerobic digestion process. Water Sci. Technol. 2012, 66, 1565-1573.

77. Procházka, J.; Dolejš, P.; Máca, J.; Dohányos, M. Stability and inhibition of anaerobic processes caused by insufficiency or excess of ammonia nitrogen. Appl. Microbiol. Biotechnol. 2012, 93, 439-447.

78. Chen, Y.; Cheng, J.J.; Creamer, K.S. Inhibition of anaerobic digestion process: A review. Bioresour. Technol. 2008, 99, 4044-4064.

79. Vyrides, I.; Santos, H.; Mingote, A.; Ray, M.J.; Stuckey, D.C. Are compatible solutes compatible with biological treatment of saline wastewater? Batch and continuous studies using submerged anaerobic membrane bioreactors (SAMBRs). Environ. Sci. Technol. 2010, 44, 7437-7442.

80. Vyrides, I.; Stuckey, D.C. Adaptation of anaerobic biomass to saline conditions: Role of compatible solutes and extracellular polysaccharides. Enzym. Microb. Technol. 2009, 44, 46-51.

81. Sasaki, K.; Morita, M.; Hirano, S.; Ohmura, N.; Igarashi, Y. Decreasing ammonia inhibition in thermophilic methanogenic bioreactors using carbon fiber textiles. Appl. Microbiol. Biotechnol. 2011, 90, 1555-1561.

82. Abouelenien, F.; Nakashimada, Y.; Nishio, N. Dry mesophilic fermentation of chicken manure for production of methane by repeated batch culture. J. Biosci. Bioeng. 2009, 107, 293-295.

83. Resch, C.; Wörl, A.; Waltenberger, R.; Braun, R.; Kirchmayr, R. Enhancement options for the utilisation of nitrogen rich animal by-products in anaerobic digestion. Bioresour. Technol. 2011, 102, 2503-2510.

84. Uludag-Demirer, S.; Demirer, G.N.; Frear, C.; Chen, S., Anaerobic digestion of dairy manure with enhanced ammonia removal. J. Environ. Manag. 2008, 86, 193-200.

85. Abdurahman, N.H.; Rosli, Y.M.; Azhari, N.H. Development of a membrane anaerobic system (MAS) for palm oil mill effluent (POME) treatment. Desalination 2011, 266, 208-212.

86. Wong, Y.S.; Kadir, M.O.A.B.; Teng, T.T. Biological kinetics evaluation of anaerobic stabilization pond treatment of palm oil mill effluent. Bioresour. Technol. 2009, 100, 4969-4975.

87. Rajagopal, R.; Torrijos, M.; Kumar, P.; Mehrotra, I. Substrate removal kinetics in high-rate upflow anaerobic filters packed with low-density polyethylene media treating high-strength agro-food wastewaters. J. Environ. Manag. 2013, 116, 101-106.

88. Kaewsuk, J.; Thorasampan, W.; Thanuttamavong, M.; Seo, J.T. Kinetic development and evaluation of membrane sequencing batch reactor (MSBR) with mixed cultures photosynthetic bacteria for dairy wastewater treatment. J. Environ. Manag. 2010, 91, 1161-1168.

89. Ramirez, I.; Volcke, E.I.P.; Rajagopal, R.; Steyer, J.P. Application of ADM1 towards modelling biodiversity in anaerobic digestion. Water Res. 2009, 43, 2787-2800.

90. Girault, R.; Bridoux, G.; Nauleau, F.; Poullain, C.; Buffet, J.; Steyer, J.-P.; Sadowski, A.G.; Béline, F. A waste characterisation procedure for ADM1 implementation based on degradation kinetics. Water Res. 2012, 46, 4099-4110.

91. Lee, M.-Y.; Suh, C.-W.; Ahn, Y.-T.; Shin, H.-S. Variation of ADM1 by using temperature-phased anaerobic digestion (TPAD) operation. Bioresour. Technol. 2009, 100, 2816-2822. 
92. Boubaker, F.; Ridha, B.C. Modelling of the mesophilic anaerobic co-digestion of olive mill wastewater with olive mill solid waste using anaerobic digestion model No. 1 (ADM1). Bioresour. Technol. 2008, 99, 6565-6577.

93. Farhan, M.H. High Rate Anaerobic Digester Systems for Brewery Wastewater Treatment and Electricity Generation: Engineering Design Factors and Cost Benefit Analysis. In Proceedings of The World Brewing Congress, Oregon Convention Centre, Portland, OR, USA, 28 July-1 August 2012; Available online: http:/www.worldbrewingcongress.org/2012/Abstracts/ AbstractsDetail.cfm?AbstractID=318 (accessed on 5 March 2013).

94. Gebrezgabher, S.A.; Meuwissen, M.P.M.; Prins, B.A.M.; Lansink, A.G.J.M.O. Economic analysis of anaerobic digestion-A case of green power biogas plant in The Netherlands. NJAS Wagening. J. Life Sci. 2010, 57, 109-115.

(C) 2013 by the authors; licensee MDPI, Basel, Switzerland. This article is an open access article distributed under the terms and conditions of the Creative Commons Attribution license (http://creativecommons.org/licenses/by/3.0/). 